\title{
JENIS-JENIS PENYAKIT GINEKOLOGI UMUM MENURUT URUTAN TERBANYAK DI BLU RSU PROF. DR. R. D. KANDO U PERIODE 1 JANUARI 2012 - 31 DESEMBER 2012
}

\author{
${ }^{1}$ Christian Berhandus \\ ${ }^{2}$ Maria F. Loho \\ ${ }^{2}$ Jhon J. E. Wantania \\ ${ }^{1}$ Kandidat Skripsi Fakultas Kedokteran Universitas Sam Ratulangi Manado \\ ${ }^{2}$ Bagian Obstetri dan Ginekologi RSUP Prof. DR. R. D. Kandou Manado \\ Email : christ_14n@yahoo.co.id
}

\begin{abstract}
ABSTRAK
Hampir setiap wanita pernah mengalami kondisi ginekologis atau infeksi dalam kehidupannya. Wanita memegang peranan utama terhadap kelanjutan generasi penerus bagi suatu negara, sehingga kesehatan wanita memberikan pengaruh yang besar. Kesehatan wanita juga merupakan parameter kemampuan negara dalam menyelenggarakan pelayanan kesehatan terhadap masyarakat. Salah satu hal yang perlu diperhatikan untuk mencapai derajat kesehatan yang optimal adalah kesehatan wanita khususnya kesehatan reproduksi karena dampaknya luas dan menyangkut berbagai aspek kehidupan.

Suatu penelitian telah dilakukan untuk mengetahui data jumlah mengenai jenis-jenis penyakit Ginekologi umum yang ada di BLU RSU Prof. Dr. R. D. Kandou pada Periode 1 Januari 31 Desember 2012. Penelitian ini merupakan suatu penelitian deskriptif retrospektif. Hasil penelitian menunjukkan bahwa, ditemukan 3 penyakit Ginekologi umum terbanyak di RSU Prof. Dr. R. D. Kandou pada Periode 1 Januari - 31 Desember 2012 yaitu Mioma Uteri (43.1\%), Kista Ovarium (41.4\%), dan Disfunctional Uterine Bleeding (4.13\%).
\end{abstract}

\section{ABSTRACT}

Almost every woman experienced gynecological disorders or infection throughout their lives. Women holds a vital role on the existence a country's next generation, and therefore the health of women will bring major impact. Women's health also serves as an indicator of a country's ability in delivering health service to the society. One of many things that we should pay attention to in order to accomplish an optimal degree of health is the health of women's reproductive organ for its broad effect and it relates to plenty of aspects of life.

A research has been conducted in order to determine the amount of data concerning the general Gynecology disease that could be found in the Public Service Agency (BLU) of Prof. Dr. R. D. Kandou General Hospital for the period of January 1st - December 31st 2012. This is a descriptive retrospective research. The result of this research shows that there are three Gynecology diseases that stand out the most in the Prof. Dr. R. D. Kandou General Hospital for the period of January 1st - December 31st 2012; Mioma Uteri (43.1\%), Kista Ovarium (41.4\%), and Disfunctional Uterine Bleeding (4.13\%). 


\section{Latar Belakang}

Dalam meningkatkan derajat kesehatan masyarakat, Ada banyak hal yang perlu diperhatikan. Salah satu diantaranya menurut pandangan yang mempunyai peranan yang cukup penting adalah menyelenggarakan pelayanan kesehatan. Pelayanan kesehatan ialah setiap upaya yang diselenggarakan secara sendiri atau bersamaan dalam suatu organisasi untuk memelihara dan meningkatkan kesehatan, mencegah dan menyembuhkan penyakit serta memulihkan kesehatan perorangan, keluarga, kelompok ataupun masyarakat (Levey dan Loomba, 1973). ${ }^{1}$

Salah satu hal yang perlu diperhatikan untuk mencapai derajat kesehatan yang optimal adalah kesehatan wanita khususnya kesehatan reproduksi karena dampaknya luas dan menyangkut berbagai aspek kehidupan. Wanita memegang peranan utama terhadap kelanjutan generasi penerus bagi suatu negara, sehingga kesehatan wanita memberikan pengaruh yang besar. Kesehatan wanita juga merupakan parameter kemampuan negara dalam menyelenggarakan pelayanan kesehatan terhadap masyarakat. $^{3}$

Kematian ibu masih menjadi tantangan utama di dunia, tak terkecuali di Indonesia. Salah satu target yang telah ditentukan dalam Millennium Development Goals (MDGs 2015) yaitu tujuan ke 5 yang meliputi meningkatkan kesehatan ibu serta mewujudkan akses kesehatan reproduksi bagi semua perempuan dimana target yang akan dicapai dari tahun 1990 sampai tahun 2015 adalah mengurangi sampai 3/4 resiko jumlah kematian. $^{4}$

Upaya untuk mewujudkan target tujuan pembangunan millenium masih membutuhkan komitmen dan usaha keras yang terus menerus. Rendahnya kesadaran masyarakat tentang kesehatan reproduksi perempuan dan pengetahuan jenis-jenis penyakit ginekologi menjadi faktor tingginya angka kematian, meskipun masih banyak faktor yang harus diperhatikan untuk menangani masalah ini. Oleh sebab itu sangat diperlukan data dari jenis-jenis penyakit ginekologi umum di tiaptiap rumah sakit.

Berdasarkan latar belakang di atas maka peneliti tertarik untuk melakukan penelitian tentang berdasarkan latar belakang masalah di atas, dapat dirumuskan permasalahan penelitian sebagai berikut:
"Jenis-jenis penyakit ginekologi umum apa saja yang ada di BLU RSU Prof. Dr. R. D. Kandou Manado Periode 1 Januari 2012 31 Desember 2012?"

\section{Rumusan Masalah}

Dengan berdasarkan latar belakang masalah di atas, dapat dirumuskan permasalahan penelitian sebagai berikut:

"Jenis-jenis penyakit ginekologi umum apa saja yang ada di BLU RSU Prof. Dr. R. D. Kandou Manado Periode 1 Januari 2012 31 Desember 2012?"

\section{Tujuan Penelitian}

\section{Tujuan Umum}

Untuk mengetahui dan mendapatkan data mengenai jenis-jenis penyakit Ginekologi umum apa saja yang ada di BLU RSU Prof. Dr. R. D. Kandou Manado Periode 1 Januari 2012 - 31 Desember 2012.

\section{Tujuan Khusus}

Untuk mengetahui dan mendapatkan data mengenai jenis-jenis penyakit ginekologi umum apa saja yang terbanyak di BLU RSU Prof. Dr. R. D. Kandou Manado Periode 1 Januari 2012 - 31 Desember 2012.

\section{Manfaat Penelitian}

Diharapkan menjadi bahan masukan dan informasi serta pertimbangan bagi stake holder dalam upaya meningkatkan wawasan dan kebutuhan tentang layanan penyakit tersebut di BLU RSU Prof. Dr. R. D. Kandou, Memberikan kontribusi dalam meningkatkan pengetahuan mengenai jenisjenis penyakit ginekologi umum terbanyak di BLU RSU Prof. Dr. R. D. Kandou bagi semuanya.

\section{METODE PENELITIAN}

Penelitian ini menggunakan desain penelitian deskriptif retrospekstif. Penelitian ini akan dilakukan pada bulan November 2012 yang berlokasi atau bertempat di ruang data bagian obstetri dan ginekologi RSU. Prof. Dr. R.D. Kandou Malalayang, Manado. Pada penelitian ini menggunakan data sekunder yaitu data yang diambil dari catatan registrasi rekam medik seluruh pasien ginekologi umum yang dirawat inap di BLU 
RSU Prof. Dr. R. D. Kandou Manado selama periode 1 Januari 2012 - 31 Desember 2012.

\section{HASIL PENELITIAN}

\section{Data Sekunder}

Pada Penelitian ini diamati jenis-jenis penyakit pasien ginekologi umum apa saja yang ada di BLU RSU Prof. Dr. R. D. Kandou Manado. Berdasarkan data registrasi rekam medik pasien Ginekologi di RSU Prof. Dr. R. D. Kandou Manado didapatkan penyakit-penyakit yang diderita pada periode 1 Januari - 31 Desember 2012 dapat dilihat pada tabel 1 .

Tabel 1. Distribusi jenis penyakit Ginekologi umum di RSU Prof. Dr. R. D. Kandou Manado Periode 1 Januari 2012 - 31 Desember 2012.

\begin{tabular}{lcc}
\hline \multicolumn{1}{c}{ Jenis Penyakit } & Jumlah & \% \\
\hline Mioma Uteri & 151 & 43.1 \\
Kista Ovarium & 145 & 41.4 \\
Disfunctional Uterin Bleeding & 14 & 4 \\
Prolapsus Uteri & 11 & 3.1 \\
Hiperplasia Endometrium & 10 & 2.8 \\
Tumor Padat Ovarium & 6 & 1.7 \\
Mioma Geburt & 5 & 1.4 \\
Endometriosis & 2 & 0.6 \\
Kista Bartolini & 2 & 0.6 \\
Bartolinitis & 1 & 0.3 \\
Polip Servik & 1 & 0.3 \\
Torsi Kista & 1 & 0.3 \\
Fistula Rectovaginal & 1 & 0.3 \\
\hline
\end{tabular}

Data sekunder RSU Prof. Dr. R. D. Kandou Manado diatas menunjukkan bahwa penyakit tertinggi ialah Moma Uteri sebanyak $151(43.1 \%)$ penderita, Kista Ovariusebanyak $145(41.4 \%)$ penderita dan DUB sebanyak 14
(4\%). Sedangkan penyakit terendah ialah, Bartolinitis, Polip Servik, Torsi Kista, dan Fistula Rektovaginal sebanyak1penderita.

\section{Data Umum}

Tabel 2. Distribusi penyakit ginekologi umum terbanyak di RSU Prof. Dr. R. D. Kandou Manado Periode 1 Januari - 31 Desember 2012.

\begin{tabular}{|c|c|c|c|c|c|c|c|c|c|c|c|c|c|}
\hline \multirow{2}{*}{ Jenis Penyakit } & \multicolumn{12}{|c|}{ Bulan } & \multirow{2}{*}{ Jumlah } \\
\hline & I & II & III & IV & $\mathrm{V}$ & VI & VII & VIII & IX & $\mathrm{X}$ & XI & XII & \\
\hline Mioma Uteri & 14 & 14 & 16 & 16 & 11 & 16 & 14 & 10 & 4 & 13 & 12 & 11 & 151 \\
\hline Kista Ovarium & 10 & 7 & 15 & 12 & 16 & 20 & 13 & 10 & 11 & 19 & & 12 & 145 \\
\hline
\end{tabular}


Berdasarkan hasil penelitian ini telah ditentukan 3 urutan jumlah penderita penyakit Ginekologi terbanyak di RSU Prof.

\section{PEMBAHASAN}

Berdasarkan hasil penelitian deskriptif retrospektif di RSU Prof. Dr. R. D. Kandou Manado dalam kurun waktu 1 tahun, yaitu dari 1 Januari 2012 sampai 31 Desember 2012, terdapat beberapa hal yang dapat disimpulkan diantaranya adalah didapatkan jenis-jenis penyakit Ginekologi umum dari 350 kasus dan 3 angka kejadian penyakit Ginekologi umum terbanyak. Selama periode tahun 2012 di RSU Prof. Dr. R. D. Kandou Manado ditemukan jumlah kasus Ginekologi umum yaitu sebanyak 350 kasus yang artinya jika ditarik jumlah rata-rata perbulan jumlah pasien Ginekologi umum yang di rawat di Ruang Ginekologi bisa mencapai 29 pasien perbulan.

Selama periode tahun 2012 Mioma Uteri ditemukan urutan tertinggi paling banyak dan menempati urutan pertama dengan 151 (43.1\%) kasus, tingginya persentase Mioma Uteri di RSU Prof. Dr. R. D. Kandou Manado sangat mencolok jika dibandingkan dengan data Nasional sendiri dimana Mioma Uteri ditemukan 2.39\% $11.70 \%$ pada semua penderita Ginekologi umum yang dirawat dan penelitian Marshall LM (1997) di Amerika Serikat yang dikutip pada daftar pustaka 10, ditemukan kasus mioma uteri yaitu 4.181 dari 327.065 wanita, prevalens rate mioma uteri 12,8 per seribu wanita. $^{10}$

Kista Ovarium menempati posisi kedua setelah Mioma Uteri, ditemukan kasus sebanyak 145 (41.4\%) kasus. Hasil ini cukup tinggi jika dibandingkan dengan data di Asia Tenggara, insiden Kista Ovarium mencapai $6,6 \%$, Angka kejadian kista ovarium di Indonesia pada tahun 2010 belum diketahui dengan pasti karena sistim pencatatan dan pelaporan yang belum akurat. Di Amerika Serikat insiden Kista Ovarium adalah sekitar 15 kasus per 100.000 wanita per tahun. Kista Ovarium didiagnosis di lebih dari 21.000
Dr. R. D. Kandou Manado Periode 1 Januari 31 Desember 2012 yaitu: Mioma Uteri, Kista Ovarium, PUA

perempuan per tahun, dan diperkirakan menyebabkan 14.600 kematian. $^{13,14}$

Di urutan ketiga ditempati oleh DUB (Disfunctional Uterine Bleeding) atau Pendarahan Uterus Abnormal (PUA) dengan jumlah yaitu 14 (4.13\%) kasus, sebagaimana yang dikutip di tinjauan pustaka 10 hasil ini dapat dikatakan cukup rendah jika di bandingkan dengan Di RSCM-FKUI pada tahun 1989 ditemukan 39\% kasus. Di Indonesia belum ada angka yang menyebutkan insidensi Disfunctional Uterine Bleeding ini secara menyeluruh. Kebanyak penulis memperkirakan insiden sama dengan di luar negeri yaitu $10 \%$ dari selruh kunjungan Ginekologik. ${ }^{15}$

\section{PENUTUP}

\section{Kesimpulan}

- Diketahui dan didapatkan data jumlah mengenai jenis-jenis penyakit Ginekologi umum yang ada di BLU RSU Prof. Dr. R. D. Kandou pada Periode 1 Januari - 31 Desember 2012.

- Ditemukan 3 penyakit Ginekologi umum terbanyak di RSU Prof. Dr. R. D. Kandou pada Periode 1 Januari - 31 Desember 2012 yaitu Mioma Uteri (43.1\%), Kista Ovarium (41.4\%), dan Disfunctional Uterine Bleeding (4.13\%).

\section{Saran}

1. Pencatatan data di registrasi rekam medik perlu diperbaiki dan dilengkapi sehingga dapat digunakan untuk penelitianpenelitian selanjutnya.

2. Hasil penelitian ini diharapkan dapat dimanfaatkan sebagai bahan acuan peningkatan pelayanan kesehatan di RSU Prof. Dr. R. D. Kandou Manado.

3. Agar kedepannya hasil penelitian ini dapat dipakai sebagai rujukan untuk penelitian yang berhubungan dengan penanganan kasus Ginekologi umum. 


\section{Ucapan Terima Kasih}

Disampaikan sebesar - besarnya kepada penguji dr. Maria F. Loho, SpOG, Dr. dr. Freddy W. Wagey, SpOG-K dan Prof. dr. Hermie Tendean, SpOG-K yang telah banyak memberikan saran, kritikan dan masukan kepada peneliti dan kepada seluruh staf bagian obstetri dan ginekologi yang telah banyak membantu dalam penelitian hingga terselesaikannya ini.

\section{DAFTAR PUSTAKA}

1. Prasetyawati, Arsita, 2008, Kedokteran Keluarga Dan Wawasannya, h 1

2. Dorland, W.A Newman. Kamus

Kedokteran Dorland. Jakarta: EGC; 2002.

3. Nugroho B. Penelitian: Kesehatan dan keselamatan kerja sebagai salah satu motivasi kerja, Salatiga; 2008. h 1.

4. Peta Jalan Percepatan Pencapaian Tujuan Pembangunan Millenium di Indonesia (BAPPENAS). 2010 [cited 2011 Okt 24]. Available from: http://phgmu.org/test/admisi/download/petajalan.pdf

5. Istilah Ginekologi dan Obstetri, 2008 [cited 27 sept 2012] available

from:http://www.drdidispog.com/2008/07/istil ah-obstetri-dan-ginelogi.html.

6. Llewellyn D, Jones, Dasar-dasar obstetri dan ginekologi. Edisi 6. Jakarta: 2001.h 3-7.

7. Ginekologi. 1981. Elstar offset. Bandung; 1981. h 31

8. Kista Ovarium, 2008 [cited 06 Jan 2013] available from:http://repository.usu.ac.id/bitstream/123 456789/27146/5/Chapter\%20I.pdf.

9. Millie A Behera, MD, 2008 Dysfunctional Uterine, Jurnal Medscape

10. Anonim. 2008. karakteristik penderita mioma uteri yang dirawat inap di RS Santa Elisabet Medan , jurnal USU

11. Jonathan S. Berek, Berek \& Novak's Gynecology, Edisi 15. Philadelphia: 2012 Lippincott Williams \& Wilkins, a Wolters Kluwer business.

12. Brimudikaviwi, Novitasari, 2012, Makalah Penyakit Infeksi Panggul, h1
13. American Cancer Society. Cancer Facts and Figures 2009. Estimated New Cancer Cases and Deaths by Sex, US, 2009. American Cancer Society. Available at http://www.cancer.org/docroot/stt/stt_0.asp?fr om=fast. (Accessed 12 December 2013.

14. P, Smith, Netter's Obstetrics \& Gynecology, Edisi 2. Philadelphia: 2008.

15. Myh, Etriyel, 2004, Pendarahan Uterus Disfungtional,

16. Ballweg, Mary Lou, Overcoming endometriosis, Edisi 1. America, 1987. Endometriosis Association, h15

17. Roger P, Smith, Netter's Obstetrics \& Gynecology, Edisi 2. Philadelphia: 2008. h128

18. Roger P, Smith, Netter's Obstetrics \& Gynecology, Edisi 2. Philadelphia: 2008. h136

19. Roger P, Smith, Netter's Obstetrics \& Gynecology, Edisi 2. Philadelphia: 2008. h109

20. Roger P, Smith, Netter's Obstetrics \& Gynecology, Edisi 2. Philadelphia: 2008. h428 